\section{SOI: $1.1 /$ TAS DOI: $10.15863 / \mathrm{TAS}$ International Scientific Journal Theoretical \& Applied Science}

p-ISSN: 2308-4944 (print) e-ISSN: 2409-0085 (online)

Year: 2017 Issue: 03 Volume: 47

Published: 10.03.2017 http://T-Science.org

SECTION 31. Economic research, finance, innovation, risk management.

\begin{abstract}
Ahmed Butt Iftikhar
Dr., Assistant Professor, University of Management Sciences \& Information Technology Kotli AK (Pakistan), butt_uck@yahoo.co.uk

Nabeel-Ud-Din Jalal Raja MS Scholar at Riphah International University, Islamabad (Pakistan), Nabeeljala121@gmail.com
\end{abstract} Khan Nisar Sehran
MS Scholar School of Public Affairs USTC,
Hefei (China)

\title{
IMPACT OF DIVIDEND POLICY ON STOCK PRICES OF FIRM
}

Abstract: Dividend is the part a firm's total net profit earned during a specified period of time. The net profit of a firm is divided among investors (the shareholders of the firm) according to their respective share of investment. Dividend policy is the most important dimension of a firm which directly influences stock prices of a firm. The firm's Board of Directors makes and implements its dividend policy with regards to profit management, distribution of profit among shareholders and to retain a part of profit in company account to avail some better investment opportunities in future. This study focuses on analyzing the impact of dividend policy on the stock prices a firm. To study the impact of dividend policy on the stock prices the banking sector firms were selected. The 10 year (2005 to 2014) financial data of five banks were collected from their financial reports and websites of State Bank of Pakistan and Karachi Stock Exchange. The results revealed that a rational dividend policy plays an important role in attracting reputable investors and contributes a lot in strengthening capital structure of a firm. The study was initiated by literature review conducted around relevant texts and journals to get awareness about previous research in the area. To get a critical view of dividend policies of different firms and relevant impact on stock prices, a large scale secondary data was taken about capital structure and relevant dividend policies of these firms. Secondary data was gathered through internet and personal visits of selected sample of respondents. The findings of the study revealed that dividend policies of a firm might have a positive and desirable impact on stock prices of a firm if devised and implemented after in-depth study of capital structure of the market and dividend policies of different firms. The results of the study are expected to help business institutions, business students and researchers to understand a distinct interdependence between dividend policies and stock prices of a firm.

Key words: Dividend, dividend policy, stock prices, investment, dividend payout.

Language: English

Citation: Iftikhar AB, Raja NJ, Sehran KN (2017) IMPACT OF DIVIDEND POLICY ON STOCK PRICES OF FIRM. ISJ Theoretical \& Applied Science, 03 (47): 32-37.

Soi: http://s-o-i.org/1.1/TAS-03-47-7 Doi: crossef https://dx.doi.org/10.15863/TAS.2017.03.47.7

\section{INTRODUCTION}

Dividend policy is recognized as one of vital strategic decisions of a firm. The dividend policy describes what amount of dividend should be paid, when to release dividend in which form, when and how much to retain for future investment and to deal with situational issues. A decline in release of dividend can reduce the value of share. Dividend is the return on investment made by an individual, group or organization. According to Fama.et al. (1996), share prices remain under direct influence of dividend policiy of a firm (either positively or negatively). Under the traditional practices it was believed that a sober dividend policy helps in acquiring the attention of investers. The financial manager works with an aim of capitalizing the wealth of the stockholders. For this financial manager formulates a fit dividend policy to boast the value of firm. A sensible dividend policy works on creating the favourable circumstances for the firm which in return is expected to boost its value in the market and gain attention of investors. The preliminary studies highlighted the fact that declaration of hike in dividend payments are expected to make positive response from investers or negative response from them in the case of fall in dividend payout. Allen and Rachim (1996) believed that there is strong relationship between dividend policy and stock prices. Whereas, Miller and Modigliani (1961) emphasized that the investor is not excited in getting the dividend and price benefits, as dividend announcement and share price are not free from each other. The information benefit and signaling effect may cause control in return and share 
prices by dividend (Gordon, 1963; Friend and Puckett, 1964; Kalay, Asquith and Mullins, 1983; Ambrish et al, 1987; Baskin, 1989). Miller and Rock (1985) argued that the announcement of dividend provides maximum information about funds flow and it helps the market to calculate the approximate earnings of firm in current period. Under the influence of signaling effect, the increase in share price is not equal to the estimated dividend and under or over valuation of prices may occur (O'Higgins, 1991).

\section{Dividend policy and stock prices}

Organization's dividend policy becomes longstanding financial strategy option during investment decision making process. A dividend policy showing high return in the form of dividend will get more attention of the shareholder. At the same time a dividend policy becomes more popular among shareholders when instead of releasing dividend in cash form, a firm holds a substantial amount of shareholders' money in stock form to avail some conducive investment opportunities. A joint study conducted by Nishat and Irfan Chaudhary (2004) concentrated to discover some facts about impact of dividend payment policies on stock prices. They took a sample of 160 companies registered at Karachi Stock Exchange for this research. The observed evaluation depended on a cross-sectional regression analysis of the relation between dividend policy and stock prices instability. Dividend policy measures both the dividend yield and payment ratio has important impact on stock price instability. The study discovered a nuber of factors which influence the divident policy and potential stock prices. These factors include investment opportunities, capital structure (annual and targetted), expected and actual financial planning and earning of the firm. Also the changes in government policies and reforms in tax agendas may also affect these policies.

\section{LITERATURE REVIEW}

There is high debate among scholars and professionals on the topic of dividend policy and its potential impact on stock prices. A number of studies found the positive link between dividend policy and stock prices. At the same time some other studies found this link negative at a given time. According to scholars dividend policy plays an important role in share price determination. At the same time dividend policy may discourage the shareholders' interest. In today's swift expansion in the stock market, organizations have to establish the most constructive policy related to dividend matters. An organization that wants to be the market leader needs to focus on dividend payout and dividend supervision issues. In the past a number of studies were undertaken to investigate relationship between dividend policies and stock prices. On dividend policies a profound work was done by Linter (1956). Linter (1956) raised the question, which is continuing essential, "which choice of manager does change the size, form and schedule of dividend payment?" In 1961 Miller and Modigliani also commenced the perception of Irrelevancy Theory of dividends. They were found of the opinion that there is no impact of dividend policy on price structure of shares. Several other researchers like Black and Scholes (1974), Chen et.al. (2002), Adefila et.al. (2004), Uddin and Choudhury (2005), Denis and Osobov (2008) and Adesola and Okwong (2009) also acknowledged the dividend irrelevancy theory and were found reluctant to accept any relationship between dividend policy and stock prices.

Contrary to the above researchers Gordon (1963) revealed a close relationship between dividend policy and stock prices. During first decade of $21^{\text {st }}$ century a number of research studies echoed the viewpoint of Gorden. Travlos et.al. (2001), Baker et.al. (2002) and Dong et.al. (2005) were found in favor of the Rellevancy Theory of dividends. In 2009 Ahmed and Javaid carried out a research to investigate the measures of dividend policy in the rising economy of Pakistan. For this research they took a sample of 320 listed companies in Karachi Stock Exchange from 2001 to 2006. In this study consequences explain that most of Pakistani firms take a decision to make payment of dividend on the basis of profits i.e. current year or preceding year profits. Those firms have large net profits distribute high amount of dividend. So the firms having high net profits pay larger dividends amount to their investors. Moreover, outcomes proved that market liquidity is positive relationship between dividend payout ratio and negative relationship was found between firm's size and payment whereas expansion opportunities and dividend payments have no relation. Outcome of the research carried out in 2009 by Adesola and Okwong that based on dividend policy, wherein they practically experienced the issues impacting the decisions of dividend of Nigerian firms prove that policies of dividend payment have significant connection among income, per share income and preceding year dividend; however, growth of firm and size contain no consequence on dividends policy.

In 2010 Akbar and Baig choose a sample of 79 corporations registered in Karachi Stocks Exchange to investigate how dividend announcement impact on share prices. This study clarifies that announcement of dividends either Cash Dividend or Share Dividend or both have positively impact on Share Price. In 2010 Nazir et.al. explored the impact of dividends payment policy on share prices. This research shows the result that dividend payment and dividend yield 
contain considerable change on share price while volume and leverage contain harmful insignificant change and income and expansion contain optimistic considerable change on stock price. Khan et.al. (2011) investigated the consequence of dividends payment policy on stock price by choosing a trial of fifty five firms registered it Karachi Stock Exchange. The Results of this study prove that dividends yield, per share income, returns on equity and after tax profits have optimistic impact on share price while retention percentage has negative relationship with Share Prices.

Nazir et.al. (2010) conducted the study to explore that how the corporate disbursement policy impact the stock price instability. From KSE a test of 73 companies was examined. The observed evaluation depended on a fix cause and random cause model regression analysis among dividends payment policy and stock prices instability beside by control inconsistent of volume, leverage, expansion and income. They established mutually the dividends policy procedures (dividend yield and payment ratio) that have an important force on the stock prices fluctuation. This proposes the share price fluctuates due to dividend policy and it gives proof behind the judge recognition effects, time cause and information cause in Pakistan. Outcomes of dividends yield to share prices instability rise for the period of 2003 to 2008, while payment percentage cover a considerable collision on minor impact level. Generally, volume and leverage contain unconstructive and no significant force on share prices insecurity. While the end result is not well-built for residential market other than dependable with the manners of growing share markets similar to Pakistan. Ahmad Kaleem and Chaudhary Salahuddin (2010) suggested that payment of dividends must have no collision on shareholders worth in the lack of dues and market limitations. Instead of paying out dividends companies must invest their excess money in different ventures that contains optimistic disposable present worth. They also propose that anticipated upcoming dividends are the source of market estimation of stocks. In spite of these abstract opinions which pay no dividends, firms frequently provide dividend to stockholders probably that shows information about the potential earnings forecast. The firms are preferred on their high share yield basis. Results proved that the shareholders do not rise worth from declaration of dividend. Definitely, investors lost a little value over a time of one month previous to dividends declaration during seven days later than ex-dividend day. Generally, fact leans toward sustain the dividends irrelevance assumptions.

Ahmed et.al., (2008) conducted a research to explore that how the dividend yield, dividend payment ratio, income per share, return on capital and net profits impact the share prices in rising markets of the Pakistan. Outcomes proved the dividends yield and dividends payment percentage has major impact on share prices. Dividends acquiesce has negatively impacted the equity prices while dividends payment percentage has optimistic considerable impact on prices of share. Outcomes are opposite to dividend irrelevancy hypothesis. While per share income and net profit have considerable positive link with share prices that shows the companies who have large per share income and net profit has higher share prices. Returns on capital have inconsequential positive change on share prices. These findings are consistent and appropriate only in promising markets like Pakistan. This investigation targeted on companies which are registered at Karachi Stock Exchange. For this analysis a section of 63 firms listed in KSE were selected, but in coming time the model volume might be improved and also other sectors and firms can be used which are registered at Islamabad and Lahore Stock Exchange. This research includes five independent variables for investigation. Some important sectors including Sugar, Chemical, Energy and Food were selected for the reseach. In 2012 Kanwal Iqbal Khan conducted a study to investigate the relationship between Dividend and Share Prices later after calculating the retention ratio, income per share and return on capital variables. For this research example of twenty five firms registered in KSE were selected. The experimental assessment on fixed and random effect Model sopported the relation between cash dividend, retention ratio and return on capital among shares market price, whereas income per share and share dividend contain negative and irrelevant relationship with stock price. This investigation also explains that Dividend Irrelevancy theory is not valid for chemical and pharmaceutical firms in Pakistan.

Nazir et.al., (2010) performed a work to investigate the impact of dividend policies on share prices. They identified the feasible factors those were reasoning impact on the stock prices whichever in rising or downward way. A number of further aspects like convertible issues, permanence issues and stability in the dividends payment are also considerably effecting the stocks estimation for banks. Dividend policy has larger impact on share price instability of the company during our present result of the research they can terminate that the deviation in share prices of the chosen banks from the economic segment has been biased by integer of dividends and associated issues. Companies who have a number of investment chances illustrate that the upcoming prediction of the company is very brilliant, so the dividend policy has a positive impact on share prices. Another study accomplished by Chen et.al., (2000) expressed that organizations that 
possess a number of investment opportunities have a considerable positive impact on share prices, on the other hand companies that have low investment opportunities have a negative reaction towards share prices. Abdullah Al Masum (2014) conducted a study to explore the relation among Dividend payment policies and Share Prices of profit-making banks of Bangladesh registered at Dhaka Stock Exchange. The pragmatic evaluation based on the fixed effect and random effect Model explains considerable pessimistic relationship between Dividends Yield and Stock Prices, whereas Retention Ratio has negative relation with Share Market Prices. This study also proves that Return on Capital and Income per share have numerically considerable positive impact on share prices and net profit has a significant negative impact on share market prices of profit-making banks of Bangladesh.

\section{METHODOLGY}

To study the impact of dividend policy on the stock prices the banking sector firms were selected. The 10 year (2005 to 2014) financial data of five banks were collected from their financial reports and websites of State Bank of Pakistan and Karachi Stock Exchange. Hypothetical statements were designed to provide direction to the study which are;

$\mathrm{H}_{1}=$ Dividend payout has significant positive impact on stock prices.
$\mathrm{H}_{2}$ =Dividend per share has positive significant impact on stock prices.

$\mathrm{H}_{3}=$ Retention ratio has significant negative impact on stock prices.

\section{Econometric Equation}

$\mathrm{SP}=\lambda_{\mathrm{O}}+\lambda_{1} \mathrm{DPR}+\lambda_{2} \mathrm{DPS}+\lambda_{3} \mathrm{RR}$

Whereas

$\mathrm{SP}=$ Stock Prices

$\mathrm{DPR}=$ Dividend Payout Ratio

DPS $=$ Dividend per Share

$\mathrm{RR}=$ Retention Ratio

\section{FINDINGS AND DISCUSSION}

The analysis was done to find out relation between independent and dependant variables. Correlation and regression analysis tools were applied to check the impact of dividend policy on the stock prices in the banking sector firms.

\subsection{Correlation Analysis}

Positive correlation between stock prices and dividend payout was found in correlation analysis $(\mathrm{r}=0.877, \mathrm{p}<0.01)$. Also it was observed that there is correlation between stock prices and dividend per share $(\mathrm{r}=0.960, \mathrm{p}<0.01)$; whereas, stock prices and retention ratio has significant negative correlation( $\mathrm{r}=-$ $0.419, \mathrm{p}<0.05)$. The following table provides the results based on correlation analysis of variables.

Table 1

\section{Correlation analysis of variables.}

\begin{tabular}{|c|c|c|c|c|c|}
\hline & Variables & Stock Prices & Dividend Payout & Dividend Per Share & Retention Ratio \\
\hline 1 & Stock Prices & - & & & \\
\hline 2 & Dividend Pay out & $0.877^{* *}$ & - & & \\
\hline 3 & Dividend Per Share & $0.960^{* *}$ & $0.354^{* *}$ & - & \\
\hline 4 & Retention Ratio & $-0.419^{*}$ & -0.283 & $-0.397^{*}$ & - \\
\hline
\end{tabular}

\subsection{Regression analysis}

As per table 2, the adjusted $\mathrm{R}^{2}$ is 0.18469 which is the defining capacity of model. The F-statistics is 103.7908 and Prob (F-statistic) is 0.000 , which mean model is fit for analysis. The data was stationary; there was no hetroskedasticity, no multicollinearity and no autocorrelation. Regression analysis was executed and it was found that if dividend payout ratio increases by one unit an increase of 19.38730 will be observed in stock prices, thus hypothesis 1 is supported. Also if one unit will increase in dividend per share, an increase of 5.373796 will be observed 


\begin{tabular}{|c|c|c|c|c|c|c|}
\hline Impact Factor: & $\begin{array}{l}\text { ISRA (India) } \\
\text { ISI (Dubai, UAF } \\
\text { GIF (Australia) } \\
\text { JIF }\end{array}$ & $\begin{array}{l}=1.344 \\
=0.829 \\
=0.564 \\
=1.500\end{array}$ & $\begin{array}{l}\text { SIS (USA) } \\
\text { PИНЦ (Russia) } \\
\text { ESJI (KZ) } \\
\text { SJIF (Morocco) }\end{array}$ & $\begin{array}{l}=0.912 \\
=0.234 \\
=1.042 \\
=2.031\end{array}$ & $\begin{array}{l}\text { ICV (Poland) } \\
\text { PIF (India) } \\
\text { IBI (India) }\end{array}$ & $\begin{array}{l}=6.630 \\
=1.940 \\
=4.260\end{array}$ \\
\hline
\end{tabular}

in Stock Prices which led towards the support of hypothesis 2 . Whereas, if one unit will increase in Retention ratio a decrease of -3.069606 will be observed in stock prices, thus hypothesis 3 is supported.

\section{Regression Analysis.}

Table 2

\begin{tabular}{llll}
\hline \hline Variable & Coefficient & Std. Error & t-Statistic \\
\hline \hline C & 12.70248 & 0.980160 & 1.35959 \\
DPO & 19.38730 & 7.515300 & $\mathbf{2 . 5 7 9 7 1 1}^{* *}$ \\
DPS & 5.373796 & 0.816350 & $\mathbf{6 . 5 8 2 7 1 4}^{* *}$ \\
RR & -3.069606 & 1.220256 & $\mathbf{- 2 . 5 1 5 5 4 3}^{* *}$ \\
\hline R-squared & & \\
Adjusted R-squared & & 0.184690 \\
F-statistic & & 0.163785 \\
Prob(F-statistic) & & 103.7908 \\
Durbin-Watson stat & & 0.000000 \\
\hline
\end{tabular}

$* * \mathrm{P}<0.001, \mathrm{DPO}=$ Dividend Payout, DPS $=$ Dividend Per Share, $\mathrm{RR}=$ Retention ratio

The results show that dividend payout and dividend per share has significant positive impact on stock prices which supports our hypothesis 1 and hypothesis 2 . These results are also aligning with the finding of Ahmed and Javaid (2009), Akbar and Baig (2010). It means that when firm issues and payout the dividend the worth of its stock in market will be increased and there will be a sense of trust regarding that firm in market and the firm debt taking capacity will boost up. However, if empirical analysis also determines that retention ratio has significant negative effect on stock prices and supports hypothesis 3 then findings will be regarded as similar to the findings of Abdullah Al Masum (2014).

\section{CONCLUSION}

The integrated results drawn out of literature review and analysis of the secondary data proved that dividend policy has a significant effect on firm's performance and firm market value. A sound policy will boost up its market share and will create sense of trust in the market which will generate favorable conditions for firms. On the basis of results the firms should focus on dividend policy in terms of gaining trust and attention of the investors. The regular dividend payment will help in high retention of investment and will improve market share of the firm and also firm's debt taking capacity will further strengthen.

\section{References:}

1. Adefila JJ, Oladipo JA, Adeoti JO (2004) The Effect of dividend policy on the market price of shares in Nigeria: case study of fifteen quoted companies. International Journal of Accounting, 2(1), 82-91.

2. Adesola WA, Okwong AE (2009) An empirical study of dividend policy of quoted companies in Nigeria. Global Journal of Social Sciences, 8(1), 85-101.
3. Ahmed Hafeez, Javid Attiya Yasmin (2008) Dynamics and determinants of dividend policy in Pakistan (Evidence from Karachi stock exchange non-financial listed firms).

4. Akbar Muhammad, Baig Humayun Habib (2010) Reaction of stock prices to dividend announcements and market efficiency in Pakistan. 


\begin{tabular}{|c|c|c|c|c|c|c|}
\hline Impact Factor: & $\begin{array}{l}\text { ISRA (India) } \\
\text { ISI (Dubai, UAE } \\
\text { GIF (Australia) } \\
\text { JIF }\end{array}$ & $\begin{array}{l}=1.344 \\
=0.829 \\
=0.564 \\
=1.500\end{array}$ & $\begin{array}{l}\text { SIS (USA) } \\
\text { PИНЦ (Russia } \\
\text { ESJI (KZ) } \\
\text { SJIF (Morocco }\end{array}$ & $\begin{array}{r}=\mathbf{0 . 9 1 2} \\
=\mathbf{0 . 2 3 4} \\
=\mathbf{1 . 0 4 2} \\
=\mathbf{2 . 0 3 1}\end{array}$ & $\begin{array}{l}\text { ICV (Poland) } \\
\text { PIF (India) } \\
\text { IBI (India) }\end{array}$ & $\begin{array}{l}=6.630 \\
=1.940 \\
=4.260\end{array}$ \\
\hline
\end{tabular}

5. Allen Dave E, Rachim Veronica S (1996) Dividend policy and stock price volatility: Australian evidence. Applied Financial Economics, 6(2), 175-188.

6. Ambarish Ramasastry, John Kose, Williams Joseph (1987) Efficient signalling with dividends and investments. The Journal of Finance, 42(2), 321-343.

7. Asquith Paul, Mullins Jr, David W (1983) The impact of initiating dividend payments on shareholders' wealth. Journal of business, 7796.

8. Baker Malcolm, Wurgler Jeffrey (2002) Market timing and capital structure. The journal of finance, 57(1), 1-32.

9. Baskin Jonathan (1989) An empirical investigation of the pecking order hypothesis. Financial management, 26-35.

10. Black Fischer, Scholes Myron (1974) The effects of dividend yield and dividend policy on common stock prices and returns. Journal of financial economics, 1(1), 1-22.

11. Chen Joseph, Hong Harrison, Stein Jeremy C (2002) Breadth of ownership and stock returns. Journal of financial Economics, 66(2), 171-205.

12. Chen Sheng-Syan, Ho Kim Wai, Lee Chengfew, Yeo Gillian HH (2000) Investment opportunities, free cash flow and market reaction to international joint ventures. Journal of Banking \& Finance, 24(11), 1747-1765.

13. Denis David J, Osobov Igor (2008) Why do firms pay dividends? International evidence on the determinants of dividend policy. Journal of Financial economics, 89(1), 62-82.

14. Deutsch Yuval, Ross Thomas W (2003) You are known by the directors you keep: Reputable directors as a signaling mechanism for young firms. Management Science, 49(8), 1003-1017.

15. Dong Ming, Robinson Chris, Veld Chris (2005) Why individual investors want dividends. Journal of Corporate Finance, 12(1), 121-158.

16. Fama Eugene F, French Kenneth R (1996) Multifactor explanations of asset pricing anomalies. The journal of finance, 51(1), 55-84.

17. Friend Irwin, Puckett Marshall (1964) Dividends and stock prices. The American Economic Review, 656-682.
18. Gordon Myron J (1959) Dividends, earnings, and stock prices. The Review of Economics and Statistics, 99-105.

19. Khan Kanwal Iqbal (2012) Effect of Dividends on Stock Prices-A Case of Chemical and Pharmaceutical Industry of Pakistan. Management, 2(5), 141-148.

20. Khan NU, Burton BM, Power DM (2011) Managerial views about dividend policy in Pakistan. Managerial Finance, 37(10), 953-970.

21. Lintner John (1962) Dividends, earnings, leverage, stock prices and the supply of capital to corporations. The review of Economics and Statistics, 243-269.

22. Miller Merton H, Modigliani Franco (1961) Dividend policy, growth, and the valuation of shares. the Journal of Business, 34(4), 411-433.

23. Miller Merton H, Rock Kevin (1985) Dividend policy under asymmetric information. The Journal of finance, 40(4), 1031-1051.

24. Nazir Mian Sajid, Nawaz Muhammad Musarat, Anwar Waseem, Ahmed Farhan (2010) Determinants of stock price volatility in karachi stock exchange: The mediating role of corporate dividend policy. International Research Journal of Finance and Economics, 55, 100-107.

25. Nishat Mohammed, Irfan Chaudhary Mohammad (2004) Dividend policy and stock price volatility in pakistan. Paper presented at the PIDE-19th Annual General Meeting and Conference.

26. O'Higgins Michael (1991) Beating the Dow: A High-return, Low-risk Method for Investing in the Dow Jones Industrial Stocks with as Little as \$5,000: HarperCollins.

27. Travlos Nickolaos, Trigeorgis Lenos, Vafeas Nikos (2001) Shareholder wealth effects of dividend policy changes in an emerging stock market: The case of Cyprus. Multinational Finance Journal, 5(2), 87-112.

28. Uddin Md Hamid, Chowdhury Golam Mohammed (2005) Effect of dividend announcement on shareholders' value: Evidence from Dhaka Stock Exchange. Journal of Business Research, 7, 61-72. 